\title{
Long-term radiological angles after anterior cervical discectomy and fusion operation made by intervertebral cage
}

\section{Intervertebral kafes ile anterior servikal diskektomi ve füzyon sonrası uzun dönem radyolojik açılar}

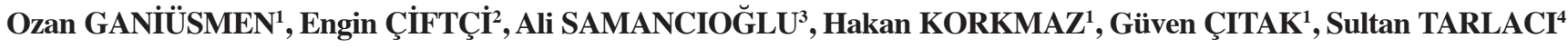 \\ ${ }^{1}$ Şifa Üniversitesi Tıp Fakültesi, Nöroşirürji Anabilim Dalı, İzmir \\ ${ }^{2}$ Denizli Devlet Hastanesi, Nöroşirürji Kliniği, İzmir \\ ${ }^{3}$ Seyfi Demirsoy Hastanesi, Nöroşirürji Kliniği İzmir \\ ${ }^{4}$ Şifa Üniversitesi Tıp Fakültesi, Nöroloji Anabilim Dalı, İzmir
}

\begin{abstract}
Objective: At present, the use of a cervical cage has become an accepted and widely practiced surgical intervention for the treatment of cervical disc disease (CDD). Polycarbon PEEK cage has been used in the treatment of cervical disc disease as a spacer with good long-term outcomes.

Methods: A retrospective study was performed with 16 consecutive patients who underwent single-level anterior cervical discectomy and fusion (ACDF) with a PEEK cage. Lateral plain radiographs were obtained both preoperatively, and at postoperative two years. Patients were followed for a minimum of 24 months.

Results: The surgical procedures used were technically successful for all patients and there were no major complications related to anesthesia or the overall surgical procedure. The mean intervertebral disc height $(\mathrm{DH})$ was $4.6 \pm 1.4 \mathrm{~mm}$ preoperatively, and height was $4.5 \pm 1.4 \mathrm{~mm}$ at the postoperative 24 -month of the follow-up period. The mean angle of lordosis (LA) was $14.5 \pm 16.8^{\circ}$ preoperatively and $17.5 \pm 13.5^{\circ}$ at the 24 -month follow-up. The mean segment angle (SA) was $13.4 \pm 15.2^{\circ}$ preoperatively, and $12.6 \pm 11.9^{\circ}$ at the 24 month of the postoperative follow-up period. There was no PEEK cage dislodgment or failure. The clinical symptoms improved in all monitored patients.

Conclusion: ACDF is an effective way for the treatment of CDD. Using a cage prevents segmental collapse. This technique can also put $\mathrm{AL}, \mathrm{SA}$ and $\mathrm{SH}$ within normal limits, so postoperative pain reduces and quality of life of the patients improve. Long-term clinical outcome of the stand-alone cages used in the surgical treatment of one cervical disc disease is satisfactory.
\end{abstract}

Key words: Anterior microdiscectomy, fusion, lordosis angle, segment angle

\section{ÖZET}

\begin{abstract}
Amaç: Zamanımızda, servikal disk hastalığının (CDH) tedavisinde servikal kafes kullanımı yaygın olarak kabul edilmiş ve bir cerrahi müdahale hâline gelmiştir. Polikarbon PEEK kafes iyi uzun vadeli sonuçlar ile servikal disk hastalığında kullanılmaktadır.

Yöntemler: İntervertebral PEEK kafes ile tek mesafe anterior servikal diskektomi ve füzyon (ACDF) uygulanan 16 hastaya retrospektif çalışma yapıldı. Preoperatif, postoperatif ve iki yıl sonra lateral düz grafiler alındı. Hastalar en az 24 ay takip edildi.

Bulgular: Kullanılan cerrahi işlemler tüm hastalar için teknik olarak başarılı olup, genel anestezi ve cerrahi ile ilgili hiçbir majör komplikasyon olmadı. Ortalama intervertebral disk yüksekliği (DY) preoperatif $4,6 \pm 1,4 \mathrm{~mm}$ ve yüksekliği 24 aylık takipte $4,5 \pm 1,4 \mathrm{~mm}$ idi. Ortalama lordoz açısı (LA) preoperatif $14,5 \pm 16,8$ iken, 24 aylık takipte $17,5 \pm 13,5$ 'tu. Ortalama segmenti açısı prepoperatif $13,4 \pm 15,2$ iken, postoperatif $12,6 \pm 11,9^{\prime}$ du. Hiçbir PEEK kafes yerinden oynamadı ya da başarısızlık olmadı. Klinik belirtiler, tüm takip hastalarda geriledi.

Sonuç: ACDF CDH tedavisi için etkili bir yoldur. Bir kafes kullanılarak segmental çökme önlenir. Bu teknik LA, SA ve DY'liğini normal sınırlar içerisinde tutarak postoperatif ağrıyı azaltır ve kaliteli yaşam sağlar. Servikal disk hastalığı cerrahi tedavisinde tek başına kafeslerin uygulanması uzun süreli takip klinik sonuçları yüz güldürücüdür.
\end{abstract}

Anahtar kelimeler: Anterior mikrodiskektomi, füzyon, lordoz açısı, segment açısı
Alındığı tarih: 22.05.2015

Kabul tarihi: 03.10.2015

Yazışma adresi: Yrd. Doç. Dr. Ozan Ganiüsmen, Fevzi Paşa Bulvarı No:172/2, Basmane 35240 İzmir

e-mail: ganiusmen@hotmail.com 


\section{INTRADUCTION}

The concept of cervical interbody fusion for the treatment of cervical disc disease has developed progressively over the last 50 years. The basic idea is to stabilize the treated segment sufficiently to allow new bone ingrowth, and to maintain disc height and avoid graft collapse until fusion occurs.

The principal advantage of cervical cage is the reduction in donor site morbidity. Since a cervical cage can provide immediate loadbearing support to the anterior column, a structural bone graft is unnecessary. Despite its several disadvantages many surgeons advocate cervical cages. Theoretically, the ideal procedure for ACDF would have no complications, promote successful arthrodesis, restore disc height, and maintain normal cervical lordosis.

From September 2008 to September 2009, a retrospective study was designed for patients who underwent single-level ACDF with a PEEK cage. Therefore the changes of cervical lordosis and segment angles are compared with literature.

\section{MATERIAL and METHODS}

\section{Patient population}

Between September 2008 and September 2009, 16 consecutive patients with single-level cervical disc herniation underwent single-level ACDF with hollow PEEK cage stabilization. Patients were included if they had severe symptomatic single-level compressive radiculopathy due to cervical disc herniation for more than three months, with compatible magnetic resonance imaging (MRI) and clinical findings. Patients with evidence of cervical instability, whiplash injury, myelopathy, systemic infection, psychiatric disturbance, metabolic bone disease, active malignancy, previous cervical spinal surgery, or drug abuse, were excluded from the study. Clinical and radiographic data were collected before, immediately after surgery and at the 24-month of the follow-up periods.

\section{Surgical technique}

Surgery was performed after the patient had received general anesthesia. A standard anterior cervical microdiscectomy, osteophytectomy, and nevre root decompression were performed in every patient. Endplate cartilage was removed with a cutting burr and curette. We used 10-12 mm long policarbon PEEK cages -with 5 degree- angle (TIP MED Medical ind. Co Itd-Izmir-Turkey) countersunk at least 1 to $2 \mathrm{~mm}$ from the ventral surface of the vertebral bodies. Each patient was instructed to use a cervical collar for protection during the first 10 postoperative weeks.

\section{Outcome measures}

Preoperatively, and at postoperative 24 months lateral plain radiographs, were obtained. Lordosis angle (LA) is meusured as the angle between lines drawn at posterior borders of $\mathrm{C} 2$ and $\mathrm{C} 7$ vertebrae on cervical roentgenograms (Figure 1). Kyphosis is defined as angle $<0^{\circ}$, lordosis is defined as angle $>10^{\circ}$. Angles between 0-10 degrees are defined as cervical straightening ${ }^{(11)}$. Segment angle is measured between a line passing through posterior of $\mathrm{C} 2$ corpus and line connecting posterior borders of upper and lower neighbor vertebras of the operated segment (Figure 2 ). Kyphosis is defined as angle $<0^{\circ}$. Lordosis is

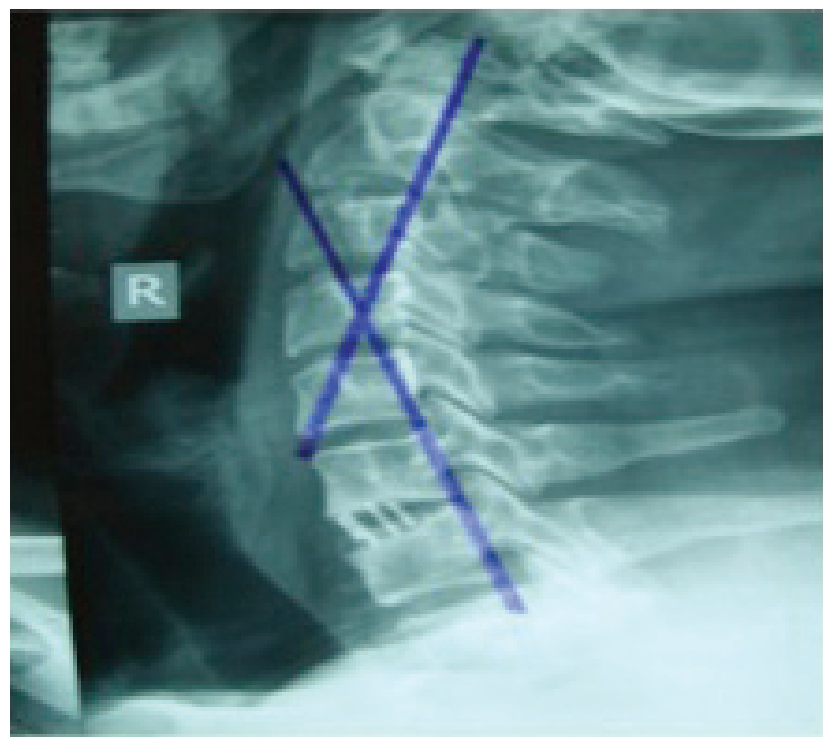

Figure 1. Lordotic angle. 
defined as angle of $\geq 1^{\circ}(3.11)$. Intraoperatively, disc distance heights were meusured on lateral roentgenograms at corpus mid points. We used $10-12 \mathrm{~mm}$ long policarbon cages with $5^{\circ}$ angle.

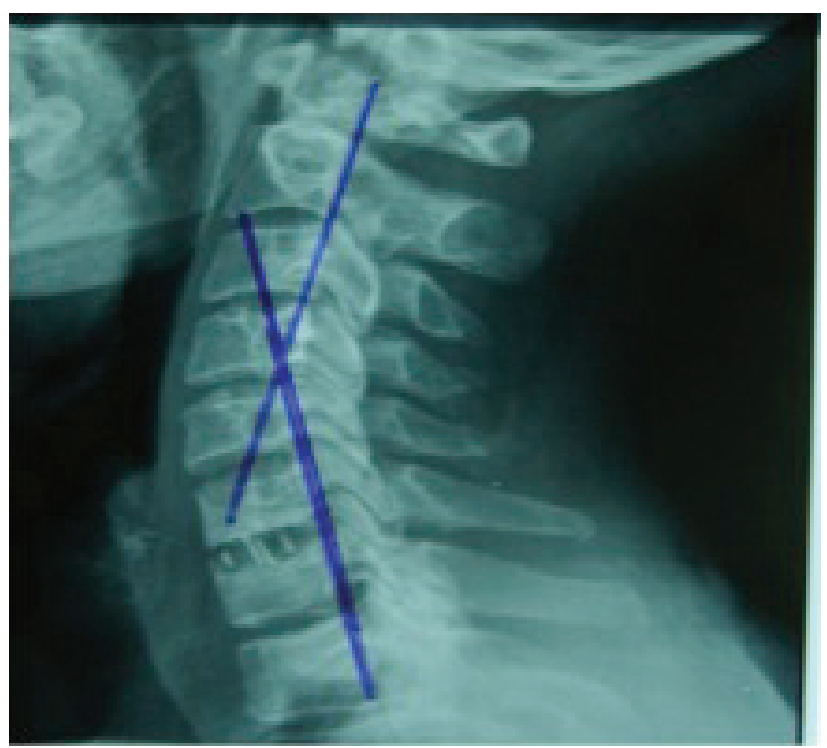

Figure 2. Segment angle.

\section{Statistical analysis}

Statistical analysis was performed using the $\mathrm{R}$ language R studio V.0.98.501 with the help of the software. The suitability of the analytical method variables with normal distribution (KolmogorovSmirnov/Shapiro-Wilk tests) were examined. Descriptive statistics was expressed as mean \pm standard deviation (Table 1). Since the angle of lordosis and segment, distance height, and pain variables in Preop,

Table 1. Preoperative and postoperative variables descriptive statistics.

\begin{tabular}{lccccc}
\hline & N (patient) & mean & Std. Deviation & Min. & Max. \\
\hline preop_LA & 16 & 14,56 & 16,828 & -10 & 50 \\
preop_SA & 16 & 13,44 & 15,293 & -15 & 35 \\
preop_DH & 16 & 4,69 & 1,448 & 2 & 8 \\
preop_Pain & 16 & 81,81 & 8,526 & 65 & 93 \\
postop_LA & 16 & 14,81 & 10,068 & 4 & 36 \\
postop_SA & 16 & 15,75 & 9,248 & 5 & 35 \\
postop_DH & 16 & 5,06 & 1,731 & 1 & 7 \\
postop_Pain & 16 & 16,56 & 15,161 & 0 & 55 \\
postop_2year_LA & 16 & 17,50 & 13,510 & -4 & 44 \\
postop_2year_SA & 16 & 12,69 & 11,993 & -5 & 32 \\
postop_2year_DH & 16 & 4,50 & 1,414 & 3 & 8 \\
postop_2year_Pain & 16 & 15,63 & 14,004 & 0 & 50 \\
& & & & & \\
\hline
\end{tabular}

LA: Lordosis Angle, SA: Segment Angle, DH: Distance Heigt
Postop and Postop 2 year groups do not show normal distribution, comparison between groups were made by using Wilcoxon test. P-value (Asymp. Sig.) of less than 0.05 was considered as statistically significant (Tables 2 and 3).

Table 2. Comparison of the angle between the preoperative and postop 2 year groups.

\begin{tabular}{lcccc}
\hline & $\begin{array}{c}\text { Preop_LA } \\
\text { Postop 2 } \\
\text { year LA }\end{array}$ & $\begin{array}{c}\text { Preop_SA } \\
\text { Postop 2 } \\
\text { year SA }\end{array}$ & $\begin{array}{c}\text { Preop_DH } \\
\text { Postop 2 } \\
\text { year DH }\end{array}$ & $\begin{array}{c}\text { Preop_Pain } \\
\text { Postop 2 } \\
\text { year Pain }\end{array}$ \\
\hline $\begin{array}{l}\text { Asymp. Sig. } \\
\text { (2-tailed) }\end{array}$ &, 711 &, 826 &, 565 &, 000 \\
\hline
\end{tabular}

Table 3. Comparison of the angle between the postoperative and postoperative-2 year groups.

\begin{tabular}{lcccc}
\hline & $\begin{array}{c}\text { Preop_LA } \\
\text { Postop 2 } \\
\text { year LA }\end{array}$ & $\begin{array}{c}\text { Preop_SA } \\
\text { Postop 2 } \\
\text { year SA }\end{array}$ & $\begin{array}{c}\text { Preop_DH } \\
\text { Postop 2 } \\
\text { year DH }\end{array}$ & $\begin{array}{c}\text { Preop_Pain } \\
\text { Postop 2 } \\
\text { year Pain }\end{array}$ \\
\hline $\begin{array}{l}\text { Asymp. Sig. } \\
\text { (2-tailed) }\end{array}$ &, 717 &, 102 &, 261 &, 027 \\
\hline
\end{tabular}

\section{Clinical outcome}

The overall clinical outcome was assessed as excellent, good, fair, or poor by the patient according to Odom's criteria ${ }^{(19)}$. Work status before surgery and at the follow-up assessments was documented. Neck and arm pain was assessed by asking the patients to quantify their degree of pain on Huskisson's visual analogue scale (VAS: $0 \mathrm{~mm}=$ no pain; $100 \mathrm{~mm}=$ worst pain possible). The group VAS values were evaluated.

\section{RESULTS}

A total of 16 patients completed the study and were followed up for at least 2 years. Their mean age was 42 years (range 26. to 61 years). The surgical procedures used were technically successful for all patients, and there were no major complications related to anesthesia or the overall surgical procedure. No hoarseness or no wound infection was noted. There was no cage dislodgment or failure.

The mean midpoint of the intervertebral body height was $4.6 \pm 1.4 \mathrm{~mm}$ preoperatively, $5.0 \pm 1.7 . \mathrm{mm}$ 
immediately aftegr the operation, (within an average of 3 days), and $4.5 \pm 1.4 \mathrm{~mm}$ at the postoperative 24 . month. The mean intervertebral disc height was about the same at the postoperative 24 . month. The mean lordosis angle was $14.5 \pm 16.8^{\circ}$ preoperatively $.14 .8 \pm 10.0^{\circ}$ immediately after the operation, and $.17 .5 \pm 13.5^{\circ}$ at the postoperative 24 . month. The lordotic angle had increased at the postoperative 24 . month (Fig. 1). The segment angle was $13.4 \pm 15.2^{\circ}$ preoperatively, $15.7 \pm 9.2^{\circ}$ immediately aftegr the operation and $12.6 \pm 11.9^{\circ}$ at the postoperative 24 . month . Pain complaints decreased from $81.8 \pm 8.5^{\circ}$ at preoperative baseline to $16.5 \pm 15.1^{\circ}$ on postoperative 3 days and $15.6 \pm 14.0^{\circ}$ at postoperative 24 . months. LA, SA, SH pretreatment, posttreatment (immediately and at postoperative 2. year) comparisons did not reveal statistically significant difference. But all results were within normal limits. The reduction in pain was statistically significant between the preoperative baseline and postoperative follow-up periods. All patients were able to return to their previous activities and improved their quality of life before the 6. month of the follow-up period. The clinical symptoms improved in all followed-up patients. The selfrated clinical outcome was excellent in $9(56.2 \%)$ patients good in 6 (\%37) and moderate in 1 (6.25\%) of the 16 patients. The mean hospitalization period was 3.5 days (range, 3 to 7 days).

\section{DISCUSSION}

CDD cause symptoms by compressing the spinal cord anteriorly or anterolaterally. If there is a surgical indication for treatment of a CDD, decompression of the spinal cord by ACD relieves the symptoms. The aim of all surgical procedures is to decompress nerve roots and the spinal cord and alleviate pain. However, segmental collapse, caused by losing $\mathrm{SH}$ because of the removal of disc material, and consequently changing of AL, become new sources of pain and discomfort for the patient ${ }^{(22)}$. After a simple ACD procedure the cervical foraminal area diminishes and new symptoms of cervical root compression can be evident ${ }^{(12)}$. Besides, removing disc material entirely results in instability in the cervical spine because of lack of support to the anterior column. The need to preserve $\mathrm{SH}$ and restore $\mathrm{AL}$ after an $\mathrm{ACD}$, and the fact that supporting the anterior column can prevent symptoms depending on these changes, led to the idea of including fusion in ACD operations. However, some distraction may occur after operation and the gap can be reduced to some extent. SH seemed unchanged after the procedures in this study. Distraction was avoided by using just the right size interbody cage instead of a cage that distracts the interbody space.In this study the segment angle was measured.

In this study, little decrease in the SA was detected. But mean LA, and SA were within normal limits. This may be because of improvement in pain. There are several clinical studies supporting the use of stand--alone cage in ACDF, but reliability of this technique remains controversial. In a multicenter study ${ }^{(10)}$ comparing the cylindrical cage with noninstrumented bone-only fusion, similar success rates were shown for the two techniques. The functional and neurological outcomes of the cages were better than that of the autogenous iliac crest graft fusion. However, based on a systematic literature review, there is limited evidence supporting the use of a cervical interbody fusion device in place of autologous bone ${ }^{(23,24)}$. There are many methods for providing fusion. Autograft, allograft, cage application and anterior plating are widely used methods. No statistically significant difference has been found among these four major methods ${ }^{(5)}$. The graft used for fusion can be easily displaced after the operation unless stabilization is achieved. Furthermore, graft materials can be compressed, so SH and AL cannot be achieved. In addition to all of these, graft particles can move to epidural areas, leading to new compression sites. Fusion materials were put in a cage to avoid graft movements and compression. At the same time, cage applications preserve $\mathrm{SH}$ and AL within normal limits. Slipping of grafts that have a cage was less frequently observed. An anterior plate can prevent 
anterior slipping and can also compress the graft to fuse quickly. Sophisticated technology produced cages that hold on to the vertebral endplates better. These cages minimized the need for an anterior plate.

All of these developments have made ACDF a popular surgical option for treatment of CDD ${ }^{(12)}$. It provides a wider angle of sight, enables removal all of the disc material and osteophytes, faciliştates bony decompression and sufficient fusion, and makes $\mathrm{ACDF}$ the preferred technique for the treatment of soft $\mathrm{CDH}^{(6,8,9,22)}$.

Adding fusion to the ACD operation diminishes $\mathrm{SH}$ losses and in parallel prevents foraminal compressions ${ }^{(18,21)}$. Although autografts provide better fusion rates, because of donor site complications and the fact that it requires more time, cage and artificial grafts are preferred ${ }^{(7,17,20)}$. Prevention of postoperative kyphosis is another advantage of cage fusion. Lordotic cages in particular can provide normal cervical alignment ${ }^{(1,2,9,13,14,16)}$. This technique can also place AL and SA within normal limits, so postoperative pain is reduced and quality of life of the patients increases ${ }^{(4,15,18)}$. Changes in Odom's criteria and VAS show that clinical improvement is parallel to these radiological measurements. In particular a sharp decline in VAS after three days of the operation may be considered as evidence of the effectiveness of this procedure.

Subsidence of the cage is another issue that needs to be considered. Many reports in the literature describe risk factors for cage subsidence ${ }^{(2,12)}$. In this study, subsidence of the cage was not encountered.To our knowledge, there are few reports of the long-term results of stand-alone cage used in ACDF. In the present study, stand-alone PEEK cages were used for the surgical treatment of one level cervical disc disease, and sixteen patients were followed up for at least 2 years. After a minimum of 2 years of follow-up both the neck and radicular pain was significantly improved. There were no complications associated with the cages. All results suggest that the long-term clinical outcome of the stand-alone cages used in the surgical treatment of one cervical disc disease is satisfactory.

\section{CONCLUSIONS}

ACDF is an effective way for the treatment of CDD. Using a PEEK cage prevents segmental collaps. This technique can also put AL and SA within normal limits, so postoperative pain is reduced, and quality of life of the patients improves. Long-term clinical outcome of the stand-alone cages used in the surgical treatment of one cervical disc disease is satisfactory. An important limitation of this study is its small sampling size. Comparative future studies about fusion rates will clarify this issue.

\section{REFERENCES}

1. Barsa P, Suchomel P. Factor saffecting sagittal malalignment dueto cage subsidence in stand alone cage assisted anterior cervical fusion. Eur Spine J 2007;16:1395-1400. http://dx.doi.org/10.1007/s00586-006-0284-8

2. Bartels RH, Donk RD, Feuth T. Subsidence of stand-alone cervical carbon fiber cages. Neurosurgery 2006;58:502-508. http://dx.doi.org/10.1227/01.NEU.0000197258.30821.50

3. Benzel EC, Norviel MF. Biomechhanics of spine stabilization. AANS Publications 2001;94-95.

4. Bertalanffy H, Eggert HR. Complications of anterior cervical discectomy without fusion in 450 consecutive patients. Acta Neurochir (Wien) 1989;99:41-50. http://dx.doi.org/10.1007/BF01407775

5. Bhadra AK, Raman AS, Casey AT, Crawford RJ. Single-level cervical radiculopathy: clinical outcome and cost-effectiveness of four techniques of anterior cervical discectomy and fusion and disc arthroplasty. Eur Spine J 2009;18:232-237. http://dx.doi.org/10.1007/s00586-008-0866-8

6. Caspar W, Barbier DD, Klara PM. Anterior cervical fusion and Caspar plate stabilization for cervical trauma. Neurosurgery 1989;25:491-502. http://dx.doi.org/10.1227/00006123-198910000-00001

7. Chau AM, Mobbs RJ. Bone graft substitutes in anterior cervical discectomy and fusion. Eur Spine J 2009;18:449-464. http://dx.doi.org/10.1007/s00586-008-0878-4

8. Connolly ES, Seymour RJ, Adams JE. Clinical evaluation of anterior cervical fusion for degenerative cervical disc disease. J Neurosurg 1965;23:431-437. http://dx.doi.org/10.3171/jns.1965.23.4.0431

9. Fielding JW. Cervical spine surgery. Past, present, and future potential. Clin Orthop Relat Res 1985;(200):284-290.

10. Hacker RJ, Cauthen JC, Gilbert TJ, Griffith SL. A prospective randomized multicenter clinical evaluation of an anterior cervical fusion cage. Spine 2000;25:2646-2654. http://dx.doi.org/10.1097/00007632-200010150-00017

11. Harrison DE, Harrison DD, Cailliet R et al. Cobb method or Harrison posterior tangent method: which to choose for lat- 
eral cervical radiographic analysis? Spine 2000;25:2072-2078. http://dx.doi.org/10.1097/00007632-200008150-00011

12. Ha SK, Park JY, Kim SH, LimSD, Lee SK. Radiologic Assessment of Subsidence in Stand-Alone Cervical Polyetheretherketone (PEEK) Cage. J Korean Neurosurg Soc 2008;44:370-374. http://dx.doi.org/10.3340/jkns.2008.44.6.370

13. Katsuura A, Hukuda S, Saruhashi Y, Mori K. Kyphotic malalignment after anterior cervical fusion is one of the factors promoting the degenerative process in adjacent intervertebral levels. Eur Spine J 2001;10:320-324. http://dx.doi.org/10.1007/s005860000243

14. Kim CH1, Chung CK, Jahng TA, Park SB, Sohn S, Lee S.Segmental Kyphosis after Cervical Interbody Fusion with Stand-alone Polyetherketone (PEEK) Cages: A Comparative Study on Two Different PEEK Cages. Spinal Disord Tech 2014 Aug 1.

15. Kim SW, Limson MA, Kim SB, et al. Comparison of radiographic changes after ACDF versus Bryan disc arthroplasty in single and bi-level cases. Eur Spine J 2009;18:218-231. http://dx.doi.org/10.1007/s00586-008-0854-z

16. Lange M, Philipp A, Fink U, Oeckler R. Anterior cervical spine fusion using RABEA-Titan-Cages avoiding iliac crest spongiosa: first experiences and results. Neurol Neurochir Pol 2000;34:64-69.

17. Lied B, Roenning PA, Sundseth J, Helseth E. Anterior cervical discectomy with fusion in patients with cervical disc degeneration: a prospective out come study of 258 patients (181 fused with autologous bone graft and 77 fused with a PEEK cage). BMC Surg 2010;10:10. http://dx.doi.org/10.1186/1471-2482-10-10

18. Dağlı M, Er U, Şimşek S, and Bavbek M. Long Term of Anterior Cervical Discectomy and Fusion with Interbody Cages. Asian Spine J 2013;7(1):34-38.

19. Odom GL, Finney W, Woodhall B. Cervical disc lesion. JAMA 1958;166:23-28. http://dx.doi.org/10.1001/jama.1958.02990010025006

20. Jyi-Feng Chen, Chieh-TsaiWu, Shih-Tseng Lee. The Use of A Hollow Polymethylmethacrylate Cervical Spacer with Plating in the Treatment of Single Level Cervical Disc Disease Chang Gung. Med J 2009, 4.

21. Topuz K, Colak A, Kaya S, et al. Two-level contiguous cervical disc disease treated with peek cages packed with demineralized bone matrix: results of 3-year follow-up. Eur Spine $J$ 2009; 18:238-243. http://dx.doi.org/10.1007/s00586-008-0869-5

22. Watters WC, 3rd, Levinthal R. Anterior cervical discectomy with and without fusion: results, complications, andlong-termfollow-up. Spine (PhilaPa 1976) 1994;19:2343-2347. http://dx.doi.org/10.1097/00007632-199410150-00016

23. Wigfield CC, Nelson RJ. Non autologous interbody fusion materials in cervical spine surgery: how strong is the evidence to justify their use? Spine 2001;26:687-694. http://dx.doi.org/10.1097/00007632-200103150-00027

24. Wu WJ1, Jiang LS, Liang Y, Dai LY. Cage subsidence does not, but cervical lordosis improvement does affect the longterm results of anterior cervical fusion withstand-alone cage for degenerative cervical disc disease: a retrospective study. Eur Spine J 2012;21(7):1374-1382. http://dx.doi.org/10.1007/s00586-011-2131-9 